\title{
The Use of Pocket Mobile Learning to Improve Critical Thinking Skills in Physics Learning
}

\author{
https://doi.org/10.3991/ijes.v6i4.8877 \\ Irnin Agustina Dwi Astuti $\left.{ }^{(}\right)$, Dasmo and Nurullaeli \\ Indraprasta PGRI University, DKI Jakarta, Indonesia \\ irnin.agustina@gmail.com
}

\begin{abstract}
The aims of the research concerned here were to the influence of using pocket mobile learning on improvement in students critical thinking skills. Pocket mobile learning is a learning media using mobile devices. This research is the quasy experiment using post test only for control group design. The independent variable is learning media in which the control group applied powerpoint, while the treatment group applied mobile pocket learning. The research data were analyzed by means of ANOVA with the significance level of $5 \%$. Based on analysis and research results can be concluded that pocket mobile learning media of specifically physics material about dynamics of motion could improve students critical thinking skills.
\end{abstract}

Keywords - pocket mobile learning, physics learning, critical thinking skills, android.

\section{Introduction}

Most of the students of Indraprasta PGRI University who take Basic Physics courses still have difficulty in mastering this course. It is not easy for students to understand experiments, formulas and solutions, graphs, and theoretical explanations at the same time. Application of concepts in physics must be linked in everyday life [1][2]. Plus the condition of students who are reluctant to read books, references, and other sources related to the concept of Physics. Based on the researcher's observation, one of the causes of students' reluctance to read a book is because the majority of Physics books are thick so it takes a lot of time to summarize and digest the contents. In addition, the books are generally presented in a rigid format with no drawings, interesting color variations, and still use a monotonous typeface.

Another condition that makes physics is still considered difficult is the method of learning by lecturers. Lessons delivered in the majority class still use lecture and discussion methods. This situation makes students bored and tired in learning Basic Physics. Therefore, it takes creativity of lecturers to make the learning atmosphere to be fun.

On the basis of the problems described above the need for innovation in learning so that the learning of physics becomes interesting. One of the interesting innovations is learning mobile learning in accordance with the current technological developments. 
The effectiveness of learning with technology has been tackled from both sides. There is evidence that the use of technology increases achievement and self-efficacy [3]. Mobile learning perspective can be classified into four, they are techno-centric, elearning focus, formal education instrument and student-centered learning [4]. Nowadays, technology empowerment at schools is used to ensure the implementation of effective learning with new opportunities and to encourage better learning performance [5]. In science learning, most require visual media or supporting tools to facilitate the understanding of the material especially for materials related to natural phenomena [1] [6].

Pocket mobile learning the power to make a transformation of learning experience and then direct learners to being able to develop divergent thinking, analyzing, and planning skills in response to things in existence around them. The divergent thinking skill is the skill of being able to elaborate on ideas creatively.

\section{$2 \quad$ Literature Review}

\subsection{Pocket Mobile Learning}

Mobile learning is a learning media using mobile devices. A term of pocket mobile learning is based on using of a technological and mobile device, such as PDA, mobile phones, laptop, and tablet in learning. State mobile learning is using of a mobile device to have possibility which can organize learning anywhere and anytime [7]. Mobile learning (m-learning) is the part of electronic learning or e-learning which gives broader opportunity in mobile mode, and better capabilities for students learning [8][9]. According to Taufiq [10], mobile learning is a new ICT improvement in education where mobile devices are used as learning media that contain of some materials or practical work aid so that they can be used inside or outside the school, and are lighter and portable. There is a virtual classroom which can be accessed anytime and anywhere, so that the learning between students and lecturers do not have to be in a face to face interaction but in the e-learning process by android. An important feature of mLearning is that one of its goals, different from those of a traditional transfer of knowledge from teacher to student, is to empower students to actively participate in the construction of their own learning [11].

\subsection{Critical Thinking Skills}

Critical thinking is the mental activity fostering original ideas and new insights [12]. The divergent thinking skill is an element for creativity and differs from creativity itself. It is the skill to think from one point as center and then to spread in various directions. One needs the divergent thinking skill to be able to generate creative ideas or, in other words, to have the creative thinking ability. Four aspects in divergent thinking, namely, the factors of fluency, flexibility, originality, and elaboration [13]. According to Abrami [14], critical thinking is partially defined by 
detecting such fallacies without regard to specific subject matter, because errors of reasoning are based on argument design rather than content.

\section{$3 \quad$ Method}

This research is the quasi-experiment using post test only for control group design. The subjects were students in Physics Education of Indraprasta University under the material of physics is Dynamics of Motion. The number of respondents was 24 students for treatment class and 26 students for the control class.

The dependent variables applied in this study was critical thinking skills. The independent variable is learning media in which the control group applied powerpoint, while the treatment group applied mobile pocket learning. The analysis technique used is the analysis of variance (ANOVA) with a margin of error (alpha) of 5\%. The critical thinking skills instrument is evaluation questions with multiple choice. The number of multiple choice are 20 questions.

\section{$4 \quad$ Result and Discussion}

\subsection{Result}

The descriptive statistics figured out the mean and standard deviation for each factor of the learning outcomes is shown in Table 1.

Table 1. Descriptive Statistic

\begin{tabular}{|c|c|c|c|c|c|c|c|c|}
\hline & \multirow{2}{*}{$\mathbf{N}$} & \multirow{2}{*}{ Mean } & \multirow{2}{*}{$\begin{array}{c}\text { Std. } \\
\text { Deviation }\end{array}$} & \multirow{2}{*}{$\begin{array}{l}\text { Std. } \\
\text { Error }\end{array}$} & \multicolumn{2}{|c|}{$\begin{array}{l}95 \% \text { Confidence } \\
\text { Interval for Mean }\end{array}$} & \multirow{2}{*}{ Minimum } & \multirow{2}{*}{ Maximum } \\
\hline & & & & & $\begin{array}{l}\text { Lower } \\
\text { Bound }\end{array}$ & $\begin{array}{l}\text { Upper } \\
\text { Bound }\end{array}$ & & \\
\hline $\begin{array}{l}\text { Treatment } \\
\text { group }\end{array}$ & 30 & 66.83 & 8.558 & 1.563 & 63.64 & 70.03 & 45 & 80 \\
\hline $\begin{array}{l}\text { Control } \\
\text { group }\end{array}$ & 30 & 50.67 & 8.277 & 1.511 & 47.58 & 53.76 & 35 & 65 \\
\hline Total & 60 & 58.75 & 11.667 & 1.506 & 55.74 & 61.76 & 35 & 80 \\
\hline
\end{tabular}

Table 1 indicates that for the critical thinking skills, group treatments had an average (66.83) which is higher than the control group (50.67). However, it needs to be analyzed whether these differences are significant enough to see the effect of learning media. This descriptive statistic displaying the effect of each independent variable through the one-way ANOVA as presented in Table 2. 
Table 2. One way Anava

\begin{tabular}{|l|l|l|l|l|l|}
\hline & \multicolumn{1}{|c|}{ Sum of Squares } & \multicolumn{1}{c|}{ df } & \multicolumn{1}{|c|}{ Mean Square } & F & \multicolumn{1}{c|}{ Sig. } \\
\hline Between Groups & 3920.417 & 1 & 3920.417 & 55.313 & .000 \\
\hline Within Groups & 4110.833 & 58 & 70.876 & & \\
\hline Total & 8031.250 & 59 & & & \\
\hline
\end{tabular}

From Table 2 above it can be seen that the critical thinking skills between the control group and treatment group were significantly different at the level of error of $5 \%$ or $95 \%$ level of confidence. So it can be said that in the critical thinking skills, the students who follow the learning media of pocket mobile learning reached the higher score than students who follow learning media with powerpoint.

\subsection{Discussion}

The use of ICT in learning process in Indonesia can be viewed in survey results [4] related to global digital statistics from the latest two years $(2014,2015)$. Although generally the penetration of internet in Indonesia just touched $28 \%$ in 2015 , but it shows significant progress compared to the attainment $15 \%$ in 2014 . The developing simultaneous growths in many sectors are predicted to boost its penetration in the future.

The use of pocket mobile learning media can influence the students' critical thinking ability compared to powerpoint. The students are more active and interactive as they relate to smartphones and can be used anytime and anywhere. Physics learning that connects the concept with the analysis can be applied with mobile learning. The students are more interested in learning physics with something different that is with pocket mobile learning. The students are able to analyze physics concepts well. Pocket mobile learning displays the abstract concept becomes real that is with the simulation of physics that explains the theories relating to everyday life.

Learning media could support learners' problem-solving and critical-thinking abilities. The use of learning media in a form of e learning could improve learning into becoming more efficient with support from the learning motivation possessed by learners and it has a sufficiently significant impact on the e-learning [15]. Indicates that learning with technological media exerts a sufficiently significant influence with learners getting a stimulation effect from the use of the media in the learning process [16].

A multimedia online learning environment actively engages learners through different types of interactivities, which can help students with learning disabilities and English learners build literacy skills, manage cognitive load, and access rich educational resources [17]. Multimedia has introduced the pedagogical strength in facilitating student learning and supplementing learning with liveliness as it adds richness and meaning to the information presentation with the use of more than one medium [18][19].

The applications of mobile learning for smartphone in physics instruction, on the one hand, additional new experiments should be developed, and this involves 
continually scanning the relevant databases of free commercial smartphone applications [20]. On the other hand, it is necessary to investigate the impact of this material-aided situated learning approach on learning and motivation and to evaluate which factor might make an used material of an experiment more successful than another, or in other words: to evaluate design or development physics experiment. The growing level of science of technology, the use of mobile learning is growing with various functions and applications.

\section{Conclusion}

Based on analysis and research results can be concluded that pocket mobile learning media of specifically physics material about dynamics of motion could improve students' critical thinking skills. The result show that the students average score with learning use pocket mobile learning is higher than learning use powerpoint.

\section{Acknowledgement}

Appreciation and gratitude are addressed to the Directorate of Research and Community Service, Directorate General of Research and Development, Ministry of Research, Technology and Higher Education who have funded the research activities of the beginner lecturer (PDP) Year 2017. Thanks also to Kopertis Territory III and Institute for Research and Community Service University of Indraprasta PGRI who has assisted this research activity.

\section{$7 \quad$ References}

[1] Astuti, I. A. D., \& Bhakti, Y. B. Interactive Learning Multimedia Based Microsoft Excel on The Temperature and Heat. Unnes Science Education Journal, vol.7, no.1, pp. 1-6, 2018.

[2] Bhakti, YB \& Astuti, IAD. The Influence Process of Science Skill and Motivation Learning with Creativity Learn. Journal of Education and Learning (EduLearn), vol. 12, no.1, pp. 30-35, 2018.

[3] Granito, M., \& Chernobilsky, E. The Effect of Technology on a Student's Motivation and Knowledge Retention. NERA Conference Proceedings 2012.

[4] Sulisworo, D., Yunita, L., \& Komalasari, A. Which Mobile Learning is More Suitable on Physics Learning in Indonesian High School? International Journal of Recent Contributions from Engineering, Science \& IT (iJES), vol.5, no.1, pp.97-104, 2017.

[5] Thinley, P., Geva, S., \& Reye, J. (2014). Tablets (iPad) for M-learning in the context of social constructivism to institute an effective learning environment. International Journal of Interactive Mobile Technologies (iJIM), vol. 8, no.1, pp. 16-20, 2014. https://doi.org/10.3991/ijim.v8i1.3452

[6] González, M. Á., González, M. Á., Martín, M. E., Llamas, C., Martínez, Ó, Vegas, J., \& Hernández, C. Teaching and learning physics with smartphones. In Blended Learning: 
Concepts, Methodologies, Tools, and Applications (pp. 866-885), 2017. IGI Global. https://doi.org/10.4018/978-1-5225-0783-3.ch044

[7] Astra, I. M., Nasbey, H., \& Nugraha, A. Development of an android application in the form of a simulation lab as learning media for senior high school students. Eurasia Journal of Mathematics, Science \& Technology Education, vol.11, no.5, pp. 1081-1088, 2015.

[8] Sulisworo, D., \& Toifur, M. The role of mobile learning on the learning environment shifting at high school in Indonesia. International Journal of Mobile Learning and Organisation, vol.10, no.3, pp. 159-170, 2016. https://doi.org/10.1504/IJMLO.2016.077864

[9] M. Alqahtani, \& H. Mohammad, "Mobile Applications' Impact on Student Performance and Satisfaction," TOJET: The Turkish Online Journal of Educational Technology, vol. 14, no. 4, pp. 102-112, 2015.

[10] Taufiq, M., Amalia, A. V., \& Parmin, P. The Development Of Science Mobile Learning With Conservation Vision Based On Android App Inventor 2. Unnes Science Education Journal, vol.6, no.1, pp. 1472-1479, 2017.

[11] De la Pena-Bandalaria, M. Impact of ICTs on open and distance learning in a developing country setting: The Philippine experience. International Review of Research in Open and Distance Learning, vol.8, no.1, pp. 1-15, 2007.

[12] Mardiana, N., \& Kuswanto, H. Android-assisted physics mobile learning to improve senior high school students' divergent thinking skills and physics HOTS. In AIP Conference Proceedings (Vol. 1868, No. 1, p. 070005), 2017.AIP Publishing.

[13] Clapham, MM. The Effect of affect Manipulation and information Exposure on Divergent Thinking. Creativity Research Journal, vol. 13, no. 3, pp.335-340, 2001. https://doi.org/10.1207/S15326934CRJ1334 11

[14] Abrami, P. C., Bernard, R. M., Borokhovski, E., Wade, A., Surkes, M. A., Tamim, R., \& Zhang, D. Instructional interventions affecting critical thinking skills and dispositions: A stage 1 meta-analysis. Review of Educational Research, vol.78, no.4, pp. 1102-1134, 2008. https://doi.org/10.3102/0034654308326084

[15] Matsuo, K., Barolli, L., Xhafa, F., Koyama, A., \& Durresi, A. Stimulating Learners Motivation in a Web-Based E-Learning System. Technologies Shaping Instruction and Distance Education: New Studies and Utilizations: New Studies and Utilizations, 223., 2009.

[16] Sakat, A. A., Zin, M. Z. M., Muhamad, R., Ahmad, A., Ahmad, N. A., \& Kasmo, M. A. Educational technology media method in teaching and learning progress. American Journal of Applied Sciences, vol. 9, no. 6, pp. 874-878, 2012. https://doi.org/10.3844/ajassp. $\underline{2012.874 .878}$

[17] Fatima E. Terrazas-Arellanes, Alejandro J. Gallard M., Lisa A. Strycker \& Emily D. Walden. Impact of interactive online units on learning science among students with learning disabilities and English learners, International Journal of Science Education, 2018. https://doi.org/10.1080/09500693.2018.1432915

[18] Leow, FT. \& Neo, M. Interactive Multimedia Learning: Innovating Classroom Education in a Malaysian University. The Turkish Online Journal of Educational Technology, vol. 13, no.2, pp. 99-110, 2014.

[19] Benedek, AG. Mindthegapp ${ }^{\mathrm{TM}}$ Between Standards And Practice of Mobile Learning Experience Design. International Journal on Advances in Education Research, vol. 2, no. 1, pp. 14-36, 2015.

[20] Kuhn, J. \& Vogt, P. Applications and Examples of Experiments with Mobile Phones and Smartphones in Physics Lessons. Frontiers in Sensors (FS), vol. 1, no. 4, pp. 68-73, 2013. 


\section{Authors}

IAD Astuti is a lecturer of Indraprasta PGRI University. She teaches Optics, management of physics laboratory, electric measuring instrument, and development of science teaching materials. She has expertise on development of education media, development of education materials, technology in physics education, and experimental of physics.

Dasmo is a lecturer of Indraprasta PGRI University. He has expertise on learning strategy, evaluation of education, and learning method.

Nurullaeli is a lecturer of Indraprasta PGRI University. She teaches Fundamental of Physics I and Fundamental of Physics II.

Article submitted 20 May 2018. Resubmitted 10 June 2018. Final acceptance 15 June 2018. Final version published as submitted by the authors. 